\title{
Determinants of Excess Liquidity: The Nigerian Experience
}

\author{
Prince C. Nwakanma ${ }^{1} \&$ Ifeanyi Mgbataogu, M. Sc ${ }^{1}$ \\ ${ }^{1}$ Department of Finance \& Banking, University of Port Harcourt, Port Harcourt, Nigeria \\ Correspondence: Prince C. Nwakanma, Department of Finance \& Banking, University of Port Harcourt, Port \\ Harcourt, Nigeria. E-mail: nwakanma5@yahoo.com
}

Received: February 2, 2014

doi: 10.5539/ ibr.v7n6p174
Accepted: March 20, 2014

Online Publication: May 27, 2014

URL:http://dx.doi.org/10.5539/ibr.v7n6p174

\begin{abstract}
Containing excess liquidity is the concern of most central banks including the Central Bank of Nigeria (CBN); this study is an attempt to ascertain the factors that account for the persistence of excess liquidity in Nigerian economy. The Vector Autoregressive (VAR) and Granger Causality tests are utilized for the study. The results are further supplemented with Impulse Response and Variance Decomposition tests. The empirical results reveal that among all the variables included in the study, level of money supply, foreign exchange monetisation, and lagged excess liquidity are the major determinants of excess liquidity in the Nigerian. The findings therefore buttress the fact that Nigerian economy as an open economy is susceptible to the dynamics of foreign economies especially the developed economies of United States as larger part of the foreign reserve is domiciled in US Dollar. Hence, the need for efficient management of foreign exchange is advocated as imperative for curbing excess liquidity. Again, we recommend effective, efficient and timely combination of monetary policy instruments to help control money supply as monetary policy rate alone cannot effectively control money supply in Nigerian economy.
\end{abstract}

Keywords: excess liquidity, foreign exchange, money supply, vector autoregression, granger causality, impulse response and variance decomposition

\section{Introduction}

Liquidity is to the economy, is what water is to the crops in the irrigation process. Crops need the right level of water for maximum yield. Thus, in irrigation process, the under-supply or over-supply of water is inimical to the yield or productivity of the crops. In the same vein, there is need for appropriate level of liquidity for economic activities to thrive in any country. Thus, government ensures adequate liquidity especially to the real sector of the economy for productive purposes. The real sector is the core of the economy, and the main driver of economic growth and development. Generally speaking, the real sector makes enormous contribution to the development of any economy, and indeed has been promoted in Nigeria as the key to the country's economic emancipation. For example, the adoption of the erstwhile Structural Adjustment Programme (SAP) in 1986 that shifted the allocation of resources to market forces was intended to make the real sector more vibrant.

Therefore the effect of the real sector in Nigeria is evident in employment generation, capital savings and mobilization, efficiency, strong linkages with other sectors, utilization of local technology, training ground for entrepreneurs, and self-reliance (Fasanya \& Onakoya, 2012). Consequently the very essence of the real sector of the Nigerian economy manifests in its contribution towards the expansion of Gross Domestic Product (GDP), employment opportunities, and the overall economic development of the nation, (Omisakin, 1999, Fasanya \& Onakoya, 2012). In this regard, government endeavours to facilitate the process of enhancing the capacity of the real sector to perform optimally by injecting liquidity into the economy so as to achieve the macroeconomic goal of full employment in the economy.

Like in irrigation process, an economy facing less or more liquidity than is needed is faced with imminent economic disaster. Thus, appropriate level of liquidity is very essential for the efficient running of the economy. Ensuring balanced liquidity in the economy is a panacea for solid and stable financial sector. A recurrent concern of central bankers is the possibility that an abundance of liquidity may hamper the ability of monetary policy to influence the level of economic activity and inflation, (Agenor \& El Aynaoui, 2008). Globally, there have been concerns about excessive accumulation of liquidity. Policy-making institutions and independent economic analysts have repeatedly pointed out the possible implications of an increase in monetary aggregate leading to excess liquidity in the domestic economy. Englama and Ogunleye (2009) noted that available data from 
International Monetary Fund (IMF) indicated that broad money worldwide in 2004 and 2005 had been on the increase since the late 1980s. Similarly, the growth of broad money has recently become obvious and also increasingly worrisome to the authorities. According to data from Central Bank of Nigeria (CBN) 2010 annual report, Broad Money Supply $\left(\mathrm{M}_{2}\right)$ grew by 6.7 per cent at end-December 2010, compared with the indicative benchmark growth rate of 29.3 per cent for fiscal 2010 and the growth of 17.5 percent at the end of the preceding year. According to the report, the sub-optimal growth in $\mathrm{M}_{2}$ was largely driven by the expansion in Domestic Credit (net) and other assets (net) of the banking systems. Correspondingly, the growth in total monetary liabilities was driven by the expansion in both narrow and quasi-money. The analysis of the composition of the total monetary liabilities $\left(\mathrm{M}_{2}\right)$ showed that the distribution was skewed towards the liquid component $\mathrm{M}_{1}$, especially in the last quarter of 2010, due to seasonal factors. Also there was an increase of 16.7 per cent in currency outside bank, compared with 3.9 per cent at end-December 2009. As a ratio of the total monetary liabilities, it rose to 9.4 per cent, from 8.6 per cent at end-December 2009.

The Central Bank of Nigeria (CBN) has described the preponderance of excess liquidity in the economy as a threat to the nation's economy especially in the area of price stability. In a bid to mitigate the effect of excess liquidity, the CBN had lately maintained restrictive monetary policy. This is reflected in retaining the Monetary Policy Rate at double digit rate of 12 per cent since November 2012. The problem of excess liquidity caused by an expansion in monetary aggregates goes beyond threat of price instability; several authors have observed that excess liquidity is likely to have adverse consequences on the ability of monetary policy to influence demand conditions and thus, to stabilize the economy. Nissanke and Aryeetey (1998), Englama and Ogunleye (2009) observe that in the presence of excess liquidity, it becomes difficult to regulate the money supply using the required reserve ratio and the money multiplier, so that the use of monetary policy for stabilization purposes is undermined. The implication is that transmission mechanism of monetary policy is weakened in the face of excess liquidity in the economy. Caprio and Honohan (1991) even painted a gloomier picture regarding the problem excess liquidity poses for monetary authority. They present the dilemma faced by policy makers in curbing excess liquidity: on the one hand, in response to excess liquidity, policy makers tend to take steps to drain off the excess so it won't lead to surge in inflation. On the other hand, this response might sometimes be ineffective because the attempt to mop up excess liquidity could lead to economic stagnation if the economy is not operating at full employment.

Ultimately, the effect of heightened liquidity is dependent on the underlying economic fundamentals. Thus, Kim (2001) discovers that an expansionary US monetary Policy shock leads to an increase in economic activity in the US. In terms of cross boarder effect, Holman and Neumann (2002) analyse the transmission of monetary shocks between the US and Canada and find that a monetary expansion in one country leads to a slight and statistically insignificant monetary contraction in the partner country. Annick et al. (2005) observe that a positive shock to these liquidity aggregates results in an increase in euro area prices, output and in the monetary aggregate $\mathrm{M}_{3}$. Canova (2005) finds that a US monetary shock has strong impact on macroeconomic developments in US. After a contractionary US monetary policy shock, interest rates are found to rise, which attracts capital inflows and pushes aggregate demand up, not down. Other authors like Bathaluddin, Nur, and Wahyu (2012); Agenor and El Aynaoui (2008) argue that excess liquidity in the economy poses huge challenge to the central banks' policy making and economic management in general. Excess liquidity, the authors agree reduces the effectiveness of monetary policy transmission mechanism. Consequently, the achievement of macroeconomic goals of full employment, higher rate of Gross Domestic Product (GDP), price stability etc. is undermined.

Despite all the arguments, the challenges and concerns expressed about presence of excess liquidity and its negative impact on the effectiveness of monetary policy and economic performance as a whole, there has been little or no attempt, known to the authors, to empirically identify the factors responsible for the phenomenon in the Nigerian economy. Therefore, this paper primarily aims at investigating the factors that predispose the Nigerian economy to the hazards of excess liquidity. The rest of this paper is structured as follows: after the introduction, the second part of the paper focuses on the relevant theories and existing empirical work on the subject matter. The third part describes the methodology employed for the study; the fourth part presents the empirical results and discussions while the fifth part of the paper caps it up with conclusions reached and policy recommendations.

\section{Theoretical Framework and Empirical Literature Review}

\subsection{Quantity Theory of Money Demand}

One of the earliest discourses on money and by extension liquidity is by an American economist Irving Fisher. Fisher examined the link between the total quantity of money and the total amount of spending on final goods 
and services produced in the economy. He believed that velocity is determined by the institutions in an economy that affect the way individuals conduct transactions. He thought the institutional and technological features of the economy would affect velocity only slowly over time, so velocity would normally be reasonably constant in the short run. From Fisher's Transactions Equations of Exchange (Quantity Theory of Money Demand), a long-run equilibrium is assumed in which actual real money balances $\left(\mathrm{M} / \mathrm{P}_{\mathrm{a}}{ }^{*}\right)$ are equal to desired real money balances $\left(\mathrm{M} / \mathrm{P}_{\mathrm{d}}^{*}\right)$ i.e.,

$$
M / P_{a}{ }^{*}=M / P_{d}{ }^{* 1 / 3}
$$

Through the injection of additional money the long-run equilibrium is disturbed. The actual money balances now exceed the desired real money balances, i.e.,

$$
M / P_{a}{ }^{*}>M / P_{d}{ }^{2 / 3}
$$

In the situation above, economic subjects actually hold more real balances than desired; this situation gives rise to Excess Liquidity in the economy.

\subsection{The Mundell-Fleming Framework}

The Mundell-Fleming model posits that an increase in money supply (expansionary monetary policy shock) reduces the local interest rate forcing it to go below the global interest rate. This consequently, triggers depreciation in the value of home currency through the resulting capital outflows to other countries of the world. Thus, global spending, as a result is directed towards domestic goods and domestic output increases - what Ruffer and Stracca (2006) refer to as Expenditure-switching effect. From the Mundell-Fleming (MF) model, the impact of monetary policy is of the "beggar-thy-neighbor" type. That is, raising domestic output at the expense of foreign output.

\subsection{The New Open Economy Models}

The New Open Economy models are sharp contrast to Mundell-Fleming (MF) model. According to the models, the basic MF result may be overturned and expansionary monetary policy increases output both at home and abroad. Thus the impact of monetary policy is no longer of the "beggar-thy-neighbor" type but "prosper-thy-neighbor". As in the MF model, the home currency depreciates as a result of the monetary expansion, which leads to a demand shift away from foreign goods. However, this intra-temporal effect may be overturned by the inter-temporal effect as initially sticky prices are expected to increase in the following period, thereby reducing the real rate of interest on foreign assets. As current period goods thus become cheaper relative to future goods, demand - both for foreign and domestic goods - is at the same time shifted towards the present (inter-temporal switching effect). If this inter-temporal aspect, which is completely absent in the MF framework, prevails a domestic monetary expansion raises foreign output.

\subsection{Empirical Findings}

Saxegaard (2006) in a paper titled, "Excess Liquidity and Effectiveness of Monetary Policy: Evidence from Sub-Saharan Africa", examined the pattern of excess liquidity in sub-Saharan Africa and its consequences for the effectiveness of monetary policy. The findings reveal that excess liquidity weakens the monetary policy transmission mechanism and thus the ability of monetary authorities to influence demand conditions in the economy. Also in the same line of argument, Englama and Ogunleye (2009) find that excess liquidity is detrimental to real output and also that shocks to excess liquidity depreciates the real effective exchange rate and reduces interest rate in the domestic economy. The implication of this according to the authors is that speculators always immediately react to shocks to excess liquidity taking advantage of excess monetary expansion for speculative activities which further depreciates exchange rate in the economy. Other authors that argue in line of challenges posed by excess liquidity in the economy include Nissanke and Aryeety (1998), Caprio and Honohan (1991), Bathaluddin et al. (2012) and Agenor and Karim (2008). Agenor and El Aynaoui (2008) for instance argue that excess liquidity in the economy poses huge challenge to the central banks' policy making and the economy in general. Excess liquidity, the authors agree reduces the effectiveness of monetary policy transmission mechanism. Thus, the achievement of macroeconomic goals of full employment, higher rate of Gross Domestic Product (GDP), price stability etc. is undermined.

On the other hand, however, Kim (2001) finds that an expansionary US monetary Policy shock leads to an increase in activity in the US. Holman and Neumann (2002) analyse the transmission of monetary shocks between the US and Canada and found that a monetary expansion in one country leads to a slight and statistically insignificant monetary contraction in the partner country. Annick et al. (2005) discover that a positive shock to these liquidity aggregates results in an increase in euro area prices, output and in the monetary aggregate $\mathrm{M}_{3}$. Canova (2005) finds that a US monetary shock has strong impact on macroeconomic developments in US. Thus 
after a contractionary US monetary policy shock, interest rates are found to rise, which attracts capital inflows and pushes aggregate demand up, not down.

On the sources of excess liquidity, Gray (2006) identifies three main sources of surplus liquidity in an economy. These sources include; Foreign exchange reserves build - asset is net Foreign Exchange reserves, Monetary financing - asset is lending to government, Bank rescue - asset is Lending of Last Resort credit, and - and possibly — ultimately a loss (i.e., a reduction in the liability item 'capital and reserves') and/or directed lending.

Bathaluddin, Nur and Wahyu (2012) identify Lag of Excess Liquidity, Lag of Money Supply and Banking systems' excess liquidity as other sources of excess liquidity in the economy. In their argument, on inflationary context, involuntary excess liquidity will be released promptly when the aggregate demand side of the banking system grows stronger.

In a work titled, "The Excess Liquidity of the Open Economy and its Management", TU et al. (2012) identify main causes of Excess Liquidity in the developing countries to include the following; Financial System, Loose monetary policies, Financial innovation, Petrodollar, East Asia Dollar, US Dollar hegemony, Over capacity, Trade supply, Savings supply, Surge of foreign exchange reserves. This study attempts to ascertain if these factors hold true in Nigerian case.

\section{Methodology}

Following the previous work by Joao and Andrea (2006), Englama and Ogunleye (2009), the study utilizes the Vector Autoregression (VAR) for empirical analysis of the data. These authors highlighted several advantages in relying on VAR methodology for the analysis of variables that could determine preponderance of Excess Liquidity in the economy.

\subsection{Model Specification}

We start by specifying a simple unrestricted VAR model. In matrix form, the VAR model is

$$
Y_{t}=A_{0}+A_{1} Y_{t-1}+e_{t}^{3 / 3}
$$

Where $Y$ is a vector of variables and $A$ is a matrix of polynomials in the lag operator and $e_{t}$ is a vector of random errors.

\subsection{Data for the Study}

The data used for this study include the annual value of excess liquidity as computed by the authors (we calculated Excess Liquidity as the ratio of Broad Money Supply to Nominal Gross Domestic Product). This follows the work of Ruffer and Stracca (2006) and also adopted by Englama and Ogunleye (2009). Other variables include; annual Money Supply, annual value of federal government deficit finance, banking system's credit to the private sector, annual value of foreign exchange monetization and Central Bank of Nigeria's Monetary Policy Rate (MPR) between the periods of 1985 and 2011.

\subsubsection{Transformation of Data}

To get a better result of fitting and make the variables in the same order of magnitude, we make appropriate transformations to Money Supply, Deficit finance, Credit to the economy and foreign assets. We proceed by generating the growth rates of Money Supply, federal government deficit finance, banking system's credit to the economy and Central Bank of Nigeria (CBN)'s monetization of foreign assets. The essence is to make all the variables appear in same unit for ease of analysis.

\subsection{Estimation Procedure}

We begin by examining the properties of the data, such as stationarity. This is to ascertain the time series properties of all the variables to avoid spurious regression, which arises as a result of the regression of two or more non-stationary time series data.

\section{Empirical Results and Discussion}

\subsection{Unit Root Tests}

Unit root tests which examine the integration properties of the variables are necessary before estimating the VAR equation(s). In our study, the Augmented Dicker-Fuller (ADF) tests are used to investigate the order of integration of the variables. Results of the tests are presented in Table 1.

The results of the Augmented Dickey-Fuller (ADF) unit root test (Table 1) show that all the variables were stationary at level (integrated of order zero) except Monetary Policy Rate (MPR) which are integrated at first difference (integrated of order one). Given the Unit root properties of the variables, we proceed to VAR 
estimation using the order of integration of the variables Chuku (2010). That is, VAR estimation of Monetary Policy Rate (MPR) at order one and Excess Liquidity (EXCL), Money Supply (MS), Deficit Finance (DEF), Credit to the economy (CRE) and Foreign Exchange Monetization (FRM) at order zero.

Table 1. ADF unit root test results

\begin{tabular}{ccc}
\hline Variables & ADF-statistic & Order of Integration \\
\hline EXCL & -4.694726 & $1(0)$ \\
MS & -3.875168 & $1(0)$ \\
DEF & -4.472955 & $1(0)$ \\
CRE & -5.082624 & $1(0)$ \\
FRM & -5.946531 & $1(0)$ \\
MPR & -5.450499 & $1(1)$ \\
\hline
\end{tabular}

Note. EXCL=Excess Liquidity; MS=Money Supply; DEF=Deficit Finance; CRE=Credit to the Economy; FRM=Foreign Reserve Monetization; MPR=Monetary Policy Rate.

Table 2. Vector autoregression estimates

Vector Autoregression Estimates

Date: 06/04/13 Time: 12:22

Sample (adjusted): 19872011

Included observations: 25 after adjustments

Standard errors in ( ) \& t-statistics in [ ]

\begin{tabular}{|c|c|c|c|c|c|c|}
\hline & EXCL & MS & DEF & CRE & FRM & $\mathrm{D}(\mathrm{MPR})$ \\
\hline \multirow[t]{3}{*}{$\operatorname{EXCL}(-1)$} & 0.783564 & -0.928089 & 0.776707 & -2.450099 & -2.583539 & 0.056865 \\
\hline & $(0.13746)$ & $(0.50062)$ & (1.41843) & $(0.97527)$ & (2.49152) & $(0.14607)$ \\
\hline & [ 5.70046] & {$[-1.85387]$} & {$[0.54758]$} & {$[-2.51222]$} & {$[-1.03693]$} & [ 0.38930$]$ \\
\hline \multirow[t]{3}{*}{ MS(-1) } & 0.116359 & 0.171495 & 0.067883 & 0.858580 & 0.560529 & -0.052538 \\
\hline & $(0.05656)$ & $(0.20600)$ & $(0.58367)$ & $(0.40131)$ & (1.02523) & $(0.06011)$ \\
\hline & [ 3.05721$]$ & {$[0.83250]$} & {$[0.11630]$} & [ 2.13943] & [ 0.54673] & {$[-0.87410]$} \\
\hline \multirow[t]{3}{*}{$\operatorname{DEF}(-1)$} & -0.004542 & 0.160795 & 0.068660 & 0.051330 & 0.575465 & 0.004641 \\
\hline & $(0.02470)$ & $(0.08996)$ & $(0.25489)$ & $(0.17525)$ & $(0.44772)$ & $(0.02625)$ \\
\hline & {$[-0.18389]$} & {$[1.78741]$} & [ 0.26938$]$ & [ 0.29289$]$ & [ 1.28534$]$ & [ 0.17682$]$ \\
\hline \multirow[t]{3}{*}{ CRE(-1) } & 0.023509 & -0.000274 & -0.607635 & -0.300148 & -0.869274 & -0.013100 \\
\hline & $(0.02891)$ & $(0.10530)$ & $(0.29835)$ & $(0.20514)$ & $(0.52406)$ & $(0.03072)$ \\
\hline & [ 0.81312$]$ & {$[-0.00260]$} & {$[-2.03666]$} & {$[-1.46316]$} & {$[-1.65873]$} & {$[-0.42637]$} \\
\hline \multirow[t]{3}{*}{ FRM(-1) } & 0.008603 & -0.035002 & -0.098516 & -0.044594 & -0.296808 & -0.000434 \\
\hline & $(0.01264)$ & $(0.04602)$ & (0.13039) & $(0.08965)$ & $(0.22903)$ & $(0.01343)$ \\
\hline & [2.68088] & {$[-0.76059]$} & {$[-0.75557]$} & {$[-0.49742]$} & {$[-1.29594]$} & {$[-0.03235]$} \\
\hline D(MPR(-1)) & 0.345379 & 0.125157 & 1.017970 & -1.497485 & -11.40030 & -0.335102 \\
\hline
\end{tabular}




\begin{tabular}{|c|c|c|c|c|c|c|}
\hline & $(0.22573)$ & $(0.82213)$ & $(2.32938)$ & $(1.60161)$ & $(4.09163)$ & $(0.23988)$ \\
\hline & [ 1.53003] & {$[0.15223]$} & [ 0.43701] & {$[-0.93499]$} & {$[-2.78625]$} & {$[-1.39697]$} \\
\hline \multirow[t]{3}{*}{$\mathrm{C}$} & 1.482940 & 42.60581 & 28.22686 & 74.87131 & 111.2394 & 0.503174 \\
\hline & $(3.87454)$ & (14.1113) & (39.9819) & (27.4904) & (70.2297) & $(4.11732)$ \\
\hline & [ 0.38274$]$ & [ 3.01927] & [ 0.70599] & [ 2.72354] & [ 1.58394$]$ & [0.12221] \\
\hline R-squared & 0.704957 & 0.277747 & 0.277392 & 0.392003 & 0.388302 & 0.175792 \\
\hline Adj. R-squared & 0.606610 & 0.036997 & 0.036523 & 0.189337 & 0.184403 & -0.098944 \\
\hline Sum sq. resids & 308.0001 & 4085.487 & 32797.24 & 15505.05 & 101193.2 & 347.8077 \\
\hline S.E. equation & 4.136559 & 15.06557 & 42.68570 & 29.34947 & 74.97895 & 4.395754 \\
\hline F-statistic & 7.168025 & 1.153672 & 1.151629 & 1.934236 & 1.904380 & 0.639859 \\
\hline Log likelihood & -66.86377 & -99.17747 & -125.2138 & -115.8490 & -139.2973 & -68.38314 \\
\hline Akaike AIC & 5.909101 & 8.494197 & 10.57710 & 9.827922 & 11.70379 & 6.030651 \\
\hline Schwarz SC & 6.250387 & 8.835483 & 10.91839 & 10.16921 & 12.04507 & 6.371936 \\
\hline Mean dependent & 23.36400 & 28.49230 & 25.81145 & 31.50681 & 42.39100 & 0.080000 \\
\hline S.D. dependent & 6.595193 & 15.35224 & 43.48722 & 32.59720 & 83.02357 & 4.193201 \\
\hline \multicolumn{2}{|c|}{ Determinant resid covariance (dof adj.) } & $2.00 \mathrm{E}+14$ & & & & \\
\hline \multicolumn{2}{|c|}{ Determinant resid covariance } & $2.79 \mathrm{E}+13$ & & & & \\
\hline \multicolumn{2}{|l|}{ Log likelihood } & -599.8468 & & & & \\
\hline \multicolumn{2}{|c|}{ Akaike information criterion } & 51.34774 & & & & \\
\hline \multicolumn{2}{|l|}{ Schwarz criterion } & 53.39545 & & & & \\
\hline
\end{tabular}

\subsection{Analysis of VAR Estimates}

From the table 2 above, let us consider the Excess Liquidity (EXCL) regression which is our main focus in this study. Looking down the EXCL VAR equation; we find that individually lagged values of Excess Liquidity, Money Supply and Monetization of foreign assets are statistically significantly related to Excess liquidity. Again, there exists a positive relationship between Excess liquidity and lagged values of the other variables included in the VAR equation except Deficit finance which showed a negative relationship.

For Money Supply, the VAR equation shows that Money supply is positively related to the lagged values of Money supply, Deficit finance and Monetary Policy Rate but negatively related to the lagged values of Excess Liquidity, Banking system credit to the economy and Foreign Exchange monetization. However, all the variables show an insignificant relationship with Money supply.

There exist a negative and significant relationship between Deficit finance and lagged value of banking system's credit to the private sector. However, the results reveal an insignificant relationship between Deficit finance and all other variables in the study. Banking system's credit to the economy is significantly related to lag values of excess liquidity and money supply but insignificantly related to the other variables of study. Finally, from the equation foreign exchange monetization and Monetary Policy Rate show insignificant relationship with the lagged values of the other variables included in the equation.

As pointed out earlier in the study, Vector autoregression gives us the relationship between a variable and its lagged values as well as the lagged values of other variables included in the equation. It is viewed as reduced form equations in which each endogenous variable is a function of its own past values and the past values of other endogenous variables in the system. It is worth mentioning here that these models do not allow one to make statements about causal relationships between variables. Even though, after estimation of the models, one can see which coefficients are significant and which ones are statistically insignificant. Thus, on its own, it is not enough for policy making purposes until the variables are further expressed in their Granger causality to ascertain the direction of influence, as well as impulse response and variance decomposition level to show the contribution a shock or innovation in each variable makes to changes in other variables. 
Therefore, we present below the Granger causality, impulse response analysis as well as the variance decomposition of our Vector autoregression equation with special emphasis on relationship between Excess Liquidity as a dependent variable on other variables in the study.

Table 3. Pairwise granger causality tests

\begin{tabular}{|c|c|c|c|}
\hline \multicolumn{4}{|l|}{ Pairwise Granger Causality Tests } \\
\hline \multicolumn{4}{|l|}{ Date: 06/12/13 Time: 09:36 } \\
\hline \multicolumn{4}{|l|}{ Sample: 19852011} \\
\hline \multicolumn{4}{|l|}{ Lags: 1} \\
\hline Null Hypothesis: & Obs & F-Statistic & Prob. \\
\hline MS does not Granger Cause EXCL & 26 & 4.83027 & 0.0383 \\
\hline EXCL does not Granger Cause MS & & 3.45128 & 0.0761 \\
\hline DEF does not Granger Cause EXCL & 26 & 0.25560 & 0.6180 \\
\hline EXCL does not Granger Cause DEF & & 1.64547 & 0.2124 \\
\hline CRE does not Granger Cause EXCL & 26 & 1.37855 & 0.2524 \\
\hline EXCL does not Granger Cause CRE & & 5.61659 & 0.0266 \\
\hline FRM does not Granger Cause EXCL & 26 & 3.40164 & 0.0425 \\
\hline EXCL does not Granger Cause FRM & & 0.04485 & 0.8341 \\
\hline D(MPR) does not Granger Cause EXCL & 25 & 1.34381 & 0.2588 \\
\hline EXCL does not Granger Cause D(MPR) & & 0.47600 & 0.4975 \\
\hline
\end{tabular}

\subsection{Analysis of Pairwise Granger Causality Test}

Granger causality test is about direction of influence between variables. It is a test of whether one time series contributes to the prediction of another time series. The test is based on comparing the mean squared error of the model with and without the variable on the right hand side. In Granger causality test, the null hypothesis is that there is no 'causality' between two variables. Thus, we try to establish causality priori, superior or inferior between variables (depending on the direction of influence). The decision rule here is that the null hypothesis is rejected if the probability value of the F-statistic given in the Pair-wise Granger Causality Tests result is less than 0.05 (our preferred level of significance), otherwise, we do not reject the null hypothesis.

The Granger causality estimation test result in Table 3 on the direction of causality reveals that the null hypothesis that Money Supply does not Granger Cause Excess Liquidity is rejected at 5\% level of significance; thus, the alternative hypothesis that Money Supply Granger Causes Excess Liquidity is accepted at 5\% level of significance. Again, the direction of influence stems from Monetization of Foreign Exchange to Excess Liquidity. We therefore reject the null hypothesis that Monetization of Foreign Exchange does no Granger Cause Excess Liquidity. The implication of this is that of all the variables examined in the study, Money Supply and Foreign exchange monetization are leading causes of excess liquidity in Nigerian economy.

Next, we proceed to Impulse Response and Variance Decomposition Tests. The Impulse Response Function (IRF) is a shock to a VAR system. Impulse responses identify the responsiveness of the dependent variables (endogenous variables) in the VAR when a shock is applied to the residuals of the variables in the VAR equation. A unit standard deviation shock is applied to each variable and the effect is observed in the VAR system. The idea is that a change (shock) in the residuals of any of the variables will bring about a change in the other variables in the VAR model.

Thus, we introduce a shock to the innovations or residuals that is on the residuals of all the variables in our VAR model to see how it affects our dependent variable (Excess liquidity) in the VAR model. Again, in calculating Impulse responses, the ordering of the variables is important; many methods are given for ordering. Hence, we have chosen Cholesky dot adjusted as given in Eviews 7 and the results are presented below. 
Table 4. Response of EXCL to One S.D. Innovations

\begin{tabular}{|c|c|c|c|c|c|c|}
\hline Period & EXCL & MS & DEF & CRE & FRM & D(MPR) \\
\hline \multirow[t]{2}{*}{1} & 3.509986 & 0.000000 & 0.000000 & 0.000000 & 0.000000 & 0.000000 \\
\hline & $(0.49639)$ & $(0.00000)$ & $(0.00000)$ & $(0.00000)$ & $(0.00000)$ & $(0.00000)$ \\
\hline \multirow[t]{2}{*}{2} & 3.331036 & 1.583748 & 0.256608 & 0.552879 & -0.787079 & 1.147097 \\
\hline & $(0.78331)$ & $(0.67579)$ & $(0.67007)$ & $(0.65495)$ & $(0.58735)$ & $(0.65652)$ \\
\hline \multirow[t]{2}{*}{3} & 2.223255 & 1.429843 & 0.254660 & 0.446675 & -0.666828 & 0.756266 \\
\hline & $(0.91865)$ & $(0.82957)$ & $(0.81015)$ & $(0.61589)$ & $(0.65110)$ & $(0.71606)$ \\
\hline \multirow[t]{2}{*}{4} & 1.347400 & 0.934117 & 0.365882 & 0.116417 & -0.557730 & 0.649146 \\
\hline & $(0.98964)$ & $(0.71644)$ & $(0.67837)$ & $(0.45643)$ & $(0.47687)$ & $(0.53325)$ \\
\hline \multirow[t]{2}{*}{5} & 0.820443 & 0.457092 & 0.265893 & 0.055781 & -0.350121 & 0.446997 \\
\hline & $(0.94685)$ & $(0.52889)$ & $(0.44679)$ & $(0.30942)$ & $(0.34214)$ & $(0.40651)$ \\
\hline \multirow[t]{2}{*}{6} & 0.571362 & 0.262212 & 0.114192 & 0.027768 & -0.203956 & 0.262558 \\
\hline & $(0.81806)$ & $(0.40007)$ & $(0.25081)$ & $(0.18284)$ & $(0.26464)$ & (0.32739) \\
\hline \multirow[t]{2}{*}{7} & 0.415401 & 0.195086 & 0.055210 & 0.046978 & -0.131947 & 0.177976 \\
\hline & $(0.65951)$ & $(0.31959)$ & $(0.16018)$ & $(0.11404)$ & $(0.21734)$ & $(0.27024)$ \\
\hline \multirow[t]{2}{*}{8} & 0.294781 & 0.156415 & 0.037698 & 0.034104 & -0.093395 & 0.115329 \\
\hline & $(0.51540)$ & $(0.25098)$ & $(0.12723)$ & $(0.07677)$ & $(0.17717)$ & $(0.22061)$ \\
\hline \multirow[t]{2}{*}{9} & 0.198297 & 0.112737 & 0.035602 & 0.023771 & -0.069266 & 0.087461 \\
\hline & $(0.40074)$ & $(0.19413)$ & $(0.10356)$ & $(0.05748)$ & $(0.13783)$ & $(0.17321)$ \\
\hline \multirow[t]{2}{*}{10} & 0.131352 & 0.073365 & 0.026905 & 0.012379 & -0.047505 & 0.058373 \\
\hline & $(0.31118)$ & $(0.14939)$ & $(0.07712)$ & $(0.04250)$ & $(0.10443)$ & $(0.13261)$ \\
\hline
\end{tabular}

Ordering: EXCL MS DEF CRE FRM D (MPR).

\subsection{Analysis of Impulse Response Estimates}

The Table 4, above shows response of Excess liquidity to One Standard Deviation innovations in the other variables included in the study over the long run period (10 years). The ordering of the variables is as shown in the table.

The Impulse Response test results show that response of Excess Liquidity (EXCL) to the innovations in the other variables over the 10 year period is positive except Foreign Reserves monetization. The test results show that the responsiveness of Excess liquidity to own shock is a positive $3.51 \%$ in the first year period, $3.33 \%$ in the second year, and $2.22 \%$ in the third year. In the sixth year, the responsiveness of Excess liquidity to its own shock reduces but still positive $0.57 \%$ and $0.13 \%$ in the tenth period. The response of Excess Liquidity to the shocks emanating from other variables (Money Supply, Deficit finance, Credit to the economy, Foreign Reserve Monetization, Monetary Policy Rate) became obvious in the second period and is $1.58 \%, 0.25 \%, 0.55 \%,-0.79 \%$ and $1.14 \%$ respectively. With respect to Money Supply, the response of Excess Liquidity to the shocks remained positive throughout the period, from positive $1.43 \%$ in the third period to positive $0.11 \%$ in the tenth period. Also, the response of Excess Liquidity to the shocks emanating from Deficit Finance, Credit to the economy and Monetary Policy Rate remained positive through the entire periods, from positive $0.25 \%, 0.45 \%$ and $0.76 \%$ in the third period to $0.03 \%, 0.01 \%$ and $0.06 \%$ respectively in the tenth period. On the other hand, Excess Liquidity responds negatively to the shocks emanating from Foreign exchange monetization. From the test results above, they show that the responsiveness of Excess liquidity to shock from Foreign Exchange Monetisation is a negative $0.79 \%$ in the second year, and negative $0.67 \%$ in the third year. In the sixth year, the responsiveness of Excess liquidity to shock in Foreign exchange monetization is negative $0.20 \%$ and $0.05 \%$ in the tenth period.

Having looked at the Impulse Response, we proceed to Variance Decomposition test. A variance decomposition or forecast error variance decomposition is used to aid in the interpretation of a vector autoregression (VAR) model once it has been fitted. The variance decomposition indicates the amount of information each variable 
contributes to the other variables in the autoregression. It determines how much of the forecast error variance of each of the variables can be explained by exogenous shocks to the other variables. Thus, while impulse response functions trace the effects of a shock to one endogenous variable on to the other variables in the VAR, variance decomposition separates the variation in an endogenous variable into the component shocks to the VAR.

Table 5. Variance decomposition

\begin{tabular}{clllllll}
\hline Period & S.E. & EXCL & MS & DEF & CRE & FRM & D(MPR) \\
\hline 1 & 3.509986 & 100.0000 & 0.000000 & 0.000000 & 0.000000 & 0.000000 & 0.000000 \\
2 & 5.313277 & 82.94385 & 8.884795 & 0.233246 & 1.082767 & 2.194381 & 4.660964 \\
3 & 6.041456 & 77.69670 & 12.47345 & 0.358088 & 1.384123 & 2.915553 & 5.172089 \\
4 & 6.329860 & 75.30900 & 13.54048 & 0.660314 & 1.294694 & 3.432279 & 5.763231 \\
5 & 6.430038 & 74.60876 & 13.62719 & 0.810896 & 1.262192 & 3.622654 & 6.068313 \\
6 & 6.470313 & 74.46262 & 13.62230 & 0.831980 & 1.248369 & 3.677058 & 6.157668 \\
7 & 6.490755 & 74.40391 & 13.62697 & 0.833983 & 1.245757 & 3.695258 & 6.194127 \\
8 & 6.501221 & 74.37014 & 13.64102 & 0.834663 & 1.244501 & 3.704007 & 6.205670 \\
9 & 6.506319 & 74.34653 & 13.64967 & 0.836349 & 1.243886 & 3.709539 & 6.214019 \\
10 & 6.508561 & 74.33606 & 13.65298 & 0.837482 & 1.243391 & 3.712311 & 6.217783 \\
\hline
\end{tabular}

Ordering: EXCL MS DEF CRE FRM D (MPR).

\subsection{Analysis of Variance Decomposition Estimates}

Table 5 above presents the empirical results of the variance decomposition of the variables in the VAR system for a ten year period into the future as with the impulse response function. As pointed out before, the variance decomposition helps to determine the total proportion of forecast error attributed to own innovation and to innovation in the other variables included in the model.

A cursory look at the Table 5 above indicates that Excess liquidity own innovation represents the dominant source of variation in the forecast error of the variable. In the variance decomposition test results, Excess liquidity accounts for $100 \%$ variation in own shock in the first year period. In the second period, $82.9 \%$ of the variation is accounted for by Excess liquidity, while Money supply, Government Deficit finance, Banking system credit to the economy, Monetization of foreign exchange and Monetary policy rate account for $8.9 \%, 0.2 \%, 1.1 \%$, $2.2 \%$ and $4.7 \%$ in that order. In the fifth year period, Excess liquidity accounts for $74.6 \%$ variation in own shock, while $13.6 \%, 0.8 \%, 1.3 \%, 3.6 \%$ and $6.2 \%$ were accounted for by Money supply, Government Deficit finance, Banking system credit to the economy, Monetization of foreign exchange and Monetary policy rate respectively. The variation remains fairly constant up until the tenth year period at $74.3 \%$ for Excess liquidity and $13.7 \%$, $0.8 \%, 1.2 \%, 3.7 \%$ and $6.2 \%$ for the other variables (Money supply, Government Deficit finance, and Banking System credit to the economy, Monetization of foreign exchange and Monetary policy rate) included in the model. Looking closely at the Variance decomposition, we notice a significant and an increasing trend in the Variation due to Money supply and Monetisation of foreign exchange. This supports the VAR and Granger causality tests that those variables are major determinants of Excess liquidity in the Nigerian economy.

\section{Conclusion and Recommendations}

Appropriate liquidity management is a necessary condition for achieving the macroeconomic goals of full employment, moderate inflation rate, and decent growth rate of Gross Domestic Product, and Balance of Payment equilibrium. However, there have been concerns about excessive accumulation of liquidity in the economy which policy makers have constantly decried stifles effective monetary policy implementation in particular and sustainable economic development in general. This paper therefore explored empirically the factors that induce persistence of excess liquidity in the Nigerian economy. From the survey of relevant literature the study identified certain factors that are known to cause excess liquidity in other climes, which have been factored into this investigation in order to test their relevance to the Nigerian economy as a developing country. The sources of excess liquidity inferred from previous studies and have been incorporated in this work comprise of money supply, deficit financing, monetization of foreign reserves, banking system's credit to the economy and 
lagged excess liquidity.

It is evident from the results that the level of money supply, foreign exchange monetisation, and lagged excess liquidity are significant as factors that cause excess liquidity in the Nigerian economy. This confirms the earlier findings by Gray (2006), Bathaluddin et al. (2012) and TU et al. (2012). The findings further buttress the fact that Nigerian economy as an open economy is susceptible to the dynamics of foreign economies especially the developed economies of United States as larger part of the foreign reserve is domiciled in US Dollar-a phenomenon TU et al. (2012) refers to as US Dollar hegemony. From the findings also, the Monetary Policy Rate of the Central Bank of Nigeria has not been effective in controlling money supply, because excess liquidity has remained untamed, and money supply is the main culprit. This may not be unconnected with the fact that in Nigeria, interest rate has never proved a viable means of controlling money supply because of the overbearing influence of government expenditure. Again, excess liquidity being one of the determinants of excess liquidity is understandably logical, because excess liquidity in one period has a natural tendency of spilling over to the next period, thereby making it self-reinforcing in successive periods.

From the foregoing, it is instructive to caution that excess liquidity is a phenomenon associated with productivity and output and as such has supply and demand sides. The monetary authority in pursuing its current contractionary monetary policy stance to mop up excess liquidity in the domestic economy, also should reconcile it with the need to shore up the absorptive capacity of the real sector of the Nigerian economy, which is actually the underlying basis for liquidity management. If the Central of Bank of Nigeria should be effective in the implementation of its monetary policy, there is need for the convergence of monetary and fiscal policies as a comprehensive package towards ensuring macroeconomic stability. Efficient management of foreign exchange is also advocated here. Monetized foreign reserves should be channeled to the productive sector of the economy for sustainable economic development. The banking supervision arm of the Central Bank of Nigeria should step up efforts in its supervision activities especially as it concerns the operators of domiciliary account. This is to monitor the recent policy of direct naira conversion of non-export foreign remittances designed to minimise the dollarisation of the domestic economy and the concomitant spillover effect on excess liquidity.

\section{References}

Annick, B., Gonsalo, C., Bjorn, F., \& Joao, S. (2005). Structural Filters for Monetary Analysis The Inflationary Movement of Money in the Euro Area. European Central Bank, Working Paper Series, No. 470/April 2005. Retrieved from http://www.ssrn.com/abstract_id=691882

Agenor, P., \& El Aynaoui, K. (2008). Excess Liquidity, Bank Pricing Rules and Monetary Policy. Centre for Growth and Business Cycle Research, Economics Studies. University of Manchester, Manchester, UK. Retrieved from http://www.ses.man.ac.uk/cgbcr/discussi.htm

Baridam, D. M. (2001). Research Methods in Administrative Sciences. Port Harcourt, Nigeria: Sherbrooke Associates.

Bathaluddin, M., Nur, M., \& Wahyu, A. W. (2012). The Impact of Excess Liquidity on Monetary Policy. Bulletin of Monetary Economics and Banking. Retrieved from http://www.bi.go.id/.../c909abcdd7ee4dea8b21076ec8623055MBarikBathalud

Brooks, C. (2008). Introductory Econometrics for Finance. Cambridge, UK: Cambridge University Press.

Canova, F. (2005). The Transmission of US to Latin America. Journal of Applied Econometrics, 20, 229-251. http://dx.doi.org/10.1002/jae.837

Caprio, G., \& Honohan, P. (1991). Excess Liquidity and Monetary Overhangs. Policy Research Working Papres, Financial Policy and Systems. Country Economics Department, the World Bank. Retrieved from http://econpapers.repec.org/RePEc:wbk:wbrwps:796

Central Bank of Nigeria. (2010). Annual Report.

Chuku, C. A. (2010). Monetary and Fiscal Policy Interactions in Nigeria: An Application of a State-Space Model with Markov-Switching. CBN Journal of Applied Statistics, 1(1), 43.

Englama, A., \& Ogunleye, T. (2009). Output, Real Exchange Rate and Interest Rate Response to Excess Liquidity in Nigeria. Central Bank of Nigeria, Economic and Financial Review, 47(1).

Fasanya, I. O., \& Onakoya, A. B. O. (2012). Informal Sector and Employment Generation in Nigeria: An Error Correction Model. Research on Humanities and Social Sciences, 2(7). Retrieved from www.iiste.org/Journals/index.php/RHSS/article/download/2620/2635 
Ganley, J. (2003). Surplus Liquidity: Implication for Central Banks. Paper presented at Centre for Central Banking Studies, Bank of England, London.

Granger, C. W. J., \& Newbold, P. (1974). Spurious Regressions in Econometrics. Journal of Econometrics, 2(2), 111-120. http://dx.doi.org/10.1016/0304-4076(74)90034-7

Granger, C. W. J. (1988). Some Recent Developments in a Concept of Causality. Journal of Econometrics, 39, 199-211. http://dx.doi.org/10.1016/0304-4076(88)90045-0

Gray, S. T. (2006). Central Bank Management of Surplus Liquidity. Paper presentation at Centre for Central Banking Studies, Bank of England, London.

Gujarati, N. D. (1995). Basic Econometrics (3rd ed.). McGraw-Hill.

Holman J. A., \& Neumann R. M. (2002). Evidence on the cross country transmission of monetary shocks. Applied Economics, 34, 1837-1857. http://dx.doi.org/10.1080/00036840210135827

IMF. International Financial Statistics. Yearbook, various issues.

Joao, M. S., \& Andrea, Z. (2006). Global Monetary Policy Shocks in the G5; A SVAR Approach. Centre for Financial Studies.

Kim, S. (2011). International Transmission of US Monetary Policy Shocks: Evidence from VARs. Journal of Monetary Economics, 48, 339-372. http://dx.doi.org/10.1016/S0304-3932(01)00080-0

Kollmann, R. (2001). The Exchange Rate in a Dynamic Optimizing Business Cycle Model with Nominal Rigidities: A Quantitative Investigation. Journal of International Economics, 55(2), 243-262. http://dx.doi.org/10.1016/S0022-1996(01)00087-3

Mohamed, A. R. S. (2013). Money, Income and Prices in Saudi Arabia. Global Journal of Management and Business Research, 13(1).

Nissanke, M., \& Aryeetey, E. (1998). Financial Integration and Development: Liberalization and Reforms in Sub-Saharan Africa London. Routledge.

Okereke, E. J., \& Sanni, T. A. (2005). Money and the Nigerian Financial System. Okigwe, Imo State Nigeria: Alvan Publications.

Omisakin, I. S. (1999). Factors influencing success or failure of an enterprise in informal sector. NISER Monograph Series, 6, 11-54.

Onoh, J. K. (2007). Dimensions of Nigeria's Monetary and Fiscal Policies-Domestic and External. Aba, Abia State, Nigeria: Astra Meridian Publishers.

Pesaran, M. H., \& Shin, Y. (1998). Generalized Impulse Response Analysis in Linear Multivariate Models. Economics Letters, 58, 17-29. http://dx.doi.org/10.1016/S0165-1765(97)00214-0

Phillips, P. C. B., \& Perron, P. (1988). Testing for a Unit Root in Time Series Regression. Biometrika, 75(2), 335-346. http://dx.doi.org/10.1093/biomet/75.2.335

Polleit, T., \& Gerdesmeier, D. (2005). Measures of Excess Liquidity. Working Paper Series. Frankfurt School of Finance \& Management, No. 65. Retrieved from http://hdl.handle.net/1041927927

Ruffer, R., \& Stracca, L. (2006). What is Global Excess Liquidity, and does it Matter? European Central Bank, Working Paper Series, No 696/Nov. 2006. Retrieved from http://www.ssrn.com/abstract_id=942737

Rule, G. (2012). The Impact of Surplus Liqudity. Paper presented at CCBS-PFTAC Course on Monetary Transmission Channels, Liquidity Conditions, and Determinants of Inflation. Central Bank of Solomon Islands, $\quad 18-23 \quad$ July, $2012 . \quad$ Retrieved from http://www.bankofengland.co.uk/education/Pages/ccbs/handbooks/ccbshb30.aspx

Saxegaard, M. (2006). Excess Liquidity and Effectiveness of Monetary Policy: Evidence from Sub-Saharan Africa. IMF Working Paper, WP/06/115. Retrieved from http://www.imf.org/external/pubs/ft/wp/2006/wp06115.pdf

Sims, C. G. (1972). Money, Income and Causality. The American Economic Review, 62(4), 540-552.

Tu, Y., Dai, W., \& Zhao, X. (2012). The Excess Liquidity of the Open Economy and its Management. International Economic Studies, 39(2), 45-54. Retrieved from http://uijs.ui.ac.ir/ies/files/site1/user_files_004740/admin-A-10-1-34-6141111.pdf

Yang, J. (2010). Expectation, Excess Liquidity and Inflation Dynamics in China. Frontiers of Economics in 
China, 5(3). Retrieved from http://link.springer.com/content/pdf/10.1007\%2Fs11459-010-0105-1.pdf

Zivot, E., \& Andrews, D. W. K. (1992). Further Evidence on the Great Crash, the Oil-Price Shock, and the Unit-Root Hypothesis. Journal of Business \& Economic Statistics, 10(3), 251-270.

\section{Copyrights}

Copyright for this article is retained by the author(s), with first publication rights granted to the journal.

This is an open-access article distributed under the terms and conditions of the Creative Commons Attribution license (http://creativecommons.org/licenses/by/3.0/). 